\title{
Microstructure and Corrosion Resistance Property of Zn-Al-Mg Alloy with Different Solidification Processes
}

\author{
Guang-rui Jiang ${ }^{1,2, a}$, Ling-feng Chen ${ }^{1}$, Hai-quan Wang ${ }^{1,3}$ and Guang-hui Liu ${ }^{1}$ \\ ${ }^{1}$ Shougang Research Institute of Technology, Beijing 100043, China \\ ${ }^{2}$ Laboratory of Green Recyclable Process for Iron \& steel Production Technology, Beijing 100043, China \\ ${ }^{3}$ National Engineering Lab of Advanced Coating Technology for Metal Materials, China Iron and Steel Research \\ Institute Group (CISRI), Beijing, 100081
}

\begin{abstract}
Zn}-\mathrm{Al}-\mathrm{Mg}$ alloy coating attracted much attention due to its high corrosion resistance properties, especially high anti-corrosion performance at the cut edge. As the Zn-Al-Mg alloy coating was usually produced by hot-dip galvanizing method, solidification process was considered to influence its microstructure and corrosion properties. In this work, a $\mathrm{Zn}-\mathrm{Al}-\mathrm{Mg}$ cast alloy was melted and cooled to room temperature with different solidification processes, including water quench, air cooling and furnace cooling. Microstructure of the alloy with different solidification processes was characterized by scanning electron microscopy (SEM). Result shows that the microstructure of the $\mathrm{Zn}-\mathrm{Al}-\mathrm{Mg}$ alloy are strongly influenced by solidification process. With increasing solidification rate, more $\mathrm{Al}$ is remained in the primary crystal. Electrochemical analysis indicates that with lowering solidification rate, the corrosion current density of the $\mathrm{Zn}-\mathrm{Al}-\mathrm{Mg}$ alloy decreases, which means higher corrosion resistance.
\end{abstract}

\section{Introduction}

To get high corrosion resistance of steel, several kinds of coatings were applied, such as galvanized coating [1], Galfan coating [2], Galvalume coating [3] and so on. Comparing with these coatings, $\mathrm{Zn}-\mathrm{Al}-\mathrm{Mg}$ alloy coating with much higher corrosion resistance in atmosphere and excellent corrosion resistance at cut edge attracted much attention in the last decades [4-7]. In the $80 \mathrm{~s}$ last century, Several $\mathrm{Zn}-\mathrm{Al}-\mathrm{Mg}$ coatings composed with $6 \mathrm{wt} . \%$ to $11 \mathrm{wt} . \% \mathrm{Al}$ and 0.5 wt. $\%$ to $3.0 \mathrm{wt} . \% \mathrm{Mg}$ were applied in Japan to prolong life of buildings[8]. Due to bad welding property and bending property with high aluminium content, some $\mathrm{Zn}-\mathrm{Al}-\mathrm{Mg}$ coatings with low aluminium content was developed in European for automobile manufacture [9].

It is considered that the microstructure of alloy play important role on the corrosion resistance properties, such as $\mathrm{Mg}-\mathrm{Al}$ alloys [10], $\mathrm{Mg}-\mathrm{Zn}$ alloys [11] and $\mathrm{Zn}-\mathrm{Al}$ alloys [12]. It is thought that the solidification process markedly effect the microstructure of alloys by casting [13-14]. However, there exist less studies on the effect of solidification process on the microstructure of the $\mathrm{Zn}$-Al-Mg alloy.

This research is focus on the effect of solidification process on the microstructure of a $\mathrm{Zn}-\mathrm{Al}-\mathrm{Mg}$ alloy with low aluminium content. With different solidification processes, the electrochemical properties were studied to reveal corrosion resistance.

${ }^{a}$ Corresponding author: guangrui82@qq.com 


\section{Experimental}

\subsection{Material}

The Zn-Al-Mg alloy was produced by casting method. Pure Zn ingot with purity of 99.995 wt.\% and pure $\mathrm{Al}$ ingot with purity of $99.6 \mathrm{wt} . \%$ were melted in a graphite crucible within a pit type resistance furnace at $500{ }^{\circ} \mathrm{C}$. Then, a master alloy composed with $11 \mathrm{wt} . \% \mathrm{Mg}$ and balanced $\mathrm{Zn}$ was dipped into the melted alloy within high purity argon gas to avoid oxidation of $\mathrm{Mg}$. The liquid $\mathrm{Zn}-\mathrm{Al}-\mathrm{Mg}$ alloy was homogenized by mechanical stirring at $450{ }^{\circ} \mathrm{C}$. After holding 1 hour, the melt was cooled to room temperature by three different processes. Part of the melt was poured into a graphite mold chilled by water (thereafter as "water quench") and a graphite mold with same dimension mounted in the air (thereafter as "air cooling"), respectively. The remaining melt was poured into a graphite mold in the furnace (thereafter as "furnace cooling"). So, the solidification rate of water quench is the fastest and that of furnace cooling is the slowest.

The casted $\mathrm{Zn}-\mathrm{Al}-\mathrm{Mg}$ alloy ingots were cut into cubic samples by $20 \mathrm{~mm}$ for tests. The composition of the alloy was tested by a SPECTRO ARCOS inductively coupled plasma spectrometer, as shown in Table 1.

Table 1. Chemical composition of the Zn-Al-Mg alloy (wt.\%)

\begin{tabular}{llll}
\hline $\mathrm{Zn}$ & $\mathrm{Al}$ & $\mathrm{Mg}$ & Bal. \\
\hline 97.30 & 1.32 & 1.10 & 0.28 \\
\hline
\end{tabular}

\subsection{Analysis methods}

The microstructure of samples was explored on a S-3400N scanning electron microscope (SEM). Attached EDS was used to investigate the element composition of the samples.

Electrochemical analysis was carried out on a CHI660 electrochemical analyzer. A three electro cell was used in electrochemical experiments, with samples surface exposed $1 \mathrm{~cm}^{2}$ as the working electrode, a platinum sheet with dimension of $30 \mathrm{~mm}$ x $30 \mathrm{~mm}$ as the counter electrode and saturated calomel electrode (SCE) as the referenced electrode. Before testing, samples were ground and polished and cleaned in ethanol. Experiments were performed in $3.5 \% \mathrm{NaCl}$ solutions. The polarization curve was obtained at a scanning speed of $1 \mathrm{mV} / \mathrm{s}$ from $-1.25 \mathrm{~V}$ vs. SCE to $-0.75 \mathrm{~V}$ vs. SCE.

\section{Results}

\subsection{Microstructure}

Microstructures are shown in Fig. 1. The chemical compositions at different location are shown in Table 2. The microstructures of samples cooled by different process are composed with a $\mathrm{Zn}$ crystal including some $\mathrm{Al}$ (position 4 in Fig. 1) and a $\mathrm{Zn}-\mathrm{Al}-\mathrm{Mg}$ ternary microstructure (position 1, 2 and 3 in Fig. 1). According to the study by Liang et al [15], the equilibrium microstructure at room temperature of the $\mathrm{Zn}-\mathrm{Al}-\mathrm{Mg}$ alloy with less than 4 wt. \% $\mathrm{Al}$ and less than 3 wt. \% $\mathrm{Mg}$ is composed of primary crystal of $\mathrm{Zn}$ and ternary eutectic crystal, which contains $\mathrm{Zn}$ solution phase, Al solution phase and $\mathrm{Mg}_{2} \mathrm{Zn}_{11}$ intermetallic phase. Therefore, during the solidification, the $\mathrm{Zn}$ crystal with slight $\mathrm{Al}$ (position 4 in Fig. 1) firstly solidified and residuary $\mathrm{Al}$ and $\mathrm{Mg}$ are rejected into the inter-dendritic region. For sample cooled by water quench, the primary crystal contains about 5.9 at. \% $\mathrm{Al}$, as shown in Table 2. As decreasing solidification rate, Al content in the primary crystal decreases markedly. For sample cooled by furnace cooling, only 2.6 at.\% Al remains in the primary crystal, as shown in Table 2. 

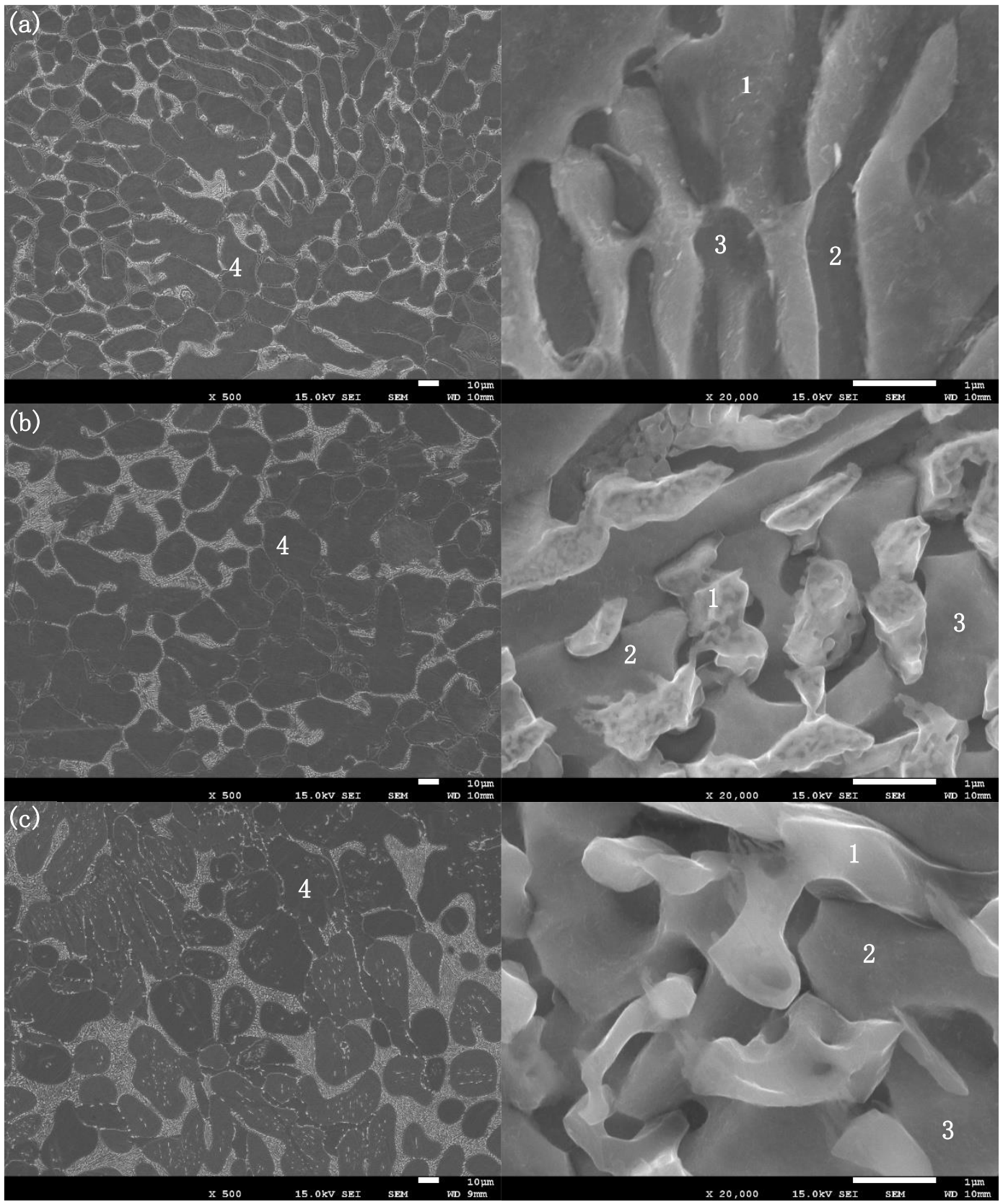

Figure 1. Microstructure of the $\mathrm{Zn}-\mathrm{Al}-\mathrm{Mg}$ alloy cooled by (a) water quench, (b) air cooling and (c) furnace cooling.

In the eutectic region, it is indicated by the EDS results that there exist three different phases with different chemical compositions, as shown in Table 2. For three different solidification processes, the atomic ratios of $\mathrm{Mg}-\mathrm{Zn}$ intermetallic phase (position 3 in Table 2) in the eutectic region are similarly near to 1:2, as shown in Table 2, which indicates that the intermetallic phase is not $\mathrm{Mg}_{2} \mathrm{Zn}_{11}$ but more likely $\mathrm{MgZn}_{2}$. It should be considered to be illustrated by the non-equilibrium reaction $\mathrm{L} \rightarrow \mathrm{Zn}+$ $\operatorname{MgZn}_{2}$ [16]. Moreover, it could be noted that the $\mathrm{Zn}$ content in the Al solution phase (position 1 in Table 2) in the eutectic region decreases along with decreasing solidification rate. For samples cooled by water quench and air cooling, the $\mathrm{Zn}$ content is 47.5 at. $\%$ and 48.1 at $\%$, respectively. For sample 
cooled by furnace cooling, the $\mathrm{Zn}$ content in the $\mathrm{Al}$ solution phase decreases to about 25.5 at.\%. It may due to the non-equilibrium and equilibrium monotectoid reaction $(\mathrm{Al}) \rightarrow(\mathrm{Al})+(\mathrm{Zn})[17]$.

Table 2. Compositions of different locations in Fig. 1

\begin{tabular}{lllll}
\hline Solidification & Position & $\mathrm{Mg}($ at. \%) & $\mathrm{Al}$ (at. \%) & $\mathrm{Zn}($ at. \%) \\
\hline \multirow{3}{*}{ Water quench } & 1 & 1.3 & 51.2 & 47.5 \\
& 2 & 5.3 & 7.1 & 87.6 \\
& 3 & 28.1 & 5.7 & 66.2 \\
& 4 & 0.0 & 5.9 & 94.1 \\
\hline \multirow{2}{*}{ Air cooling } & 1 & 1.5 & 50.5 & 48.1 \\
& 2 & 3.8 & 6.4 & 89.7 \\
& 3 & 32.8 & 2.6 & 64.6 \\
Furnace cooling & 4 & 0.0 & 4.7 & 95.3 \\
& 1 & 1.2 & 73.3 & 25.5 \\
& 2 & 0.0 & 3.9 & 96.1 \\
& 3 & 26.9 & 1.8 & 71.4 \\
\hline
\end{tabular}

\subsection{Electrochemical properties}

Fig. 2 shows Tafel curves. Electrochemical properties are shown in Table 3, which were determined by the Tafel extrapolation method [18]. The shape of Tafel curves are similar for all three processes. Corrosion current densities in anodic polarization curves increase sharply and reach to a plateau, which indicate a high dissolution behavior. In the low catholic overpotential region, the corrosion current densities increase slowly. As the value of corrosion potentials $\left(E_{\text {corr }}\right)$ is less than-1.2 V vs. SCE, the corrosion current densities increase sharply, which implies cathodic reactions i.e. hydrogen evolution reaction and/or oxygen reduction reaction. The values of corrosion potential are similar for all samples. However, the values of corrosion current densities $\left(I_{\text {corr }}\right)$ show much more difference. For water quench sample and air cooling sample, the values of $I_{\text {corr }}$ are $5.8 \mathrm{~A} \cdot \mathrm{cm}^{-2}$ and $5.5 \mathrm{~A} \cdot \mathrm{cm}^{-2}$, respectively. For furnace cooling sample, the value of $I_{\text {corr }}$ sharply decreases to $3.7 \mathrm{~A} \cdot \mathrm{cm}^{-2}$. According to standard of ASTM G 102, corrosion rate could be calculated by corrosion current density:

$$
R=\mathrm{k} I_{\text {corr }} W
$$

where $R$ is the corrosion rate, $\mathrm{k}$ is a constant value, $W$ is the equivalent weight. Therefore, the corrosion rate is proportional to the corrosion current density for the $\mathrm{Zn}-\mathrm{Al}-\mathrm{Mg}$ alloy. So, the corrosion rate of furnace cooling sample is about sixty-three percent of that of water quench sample.

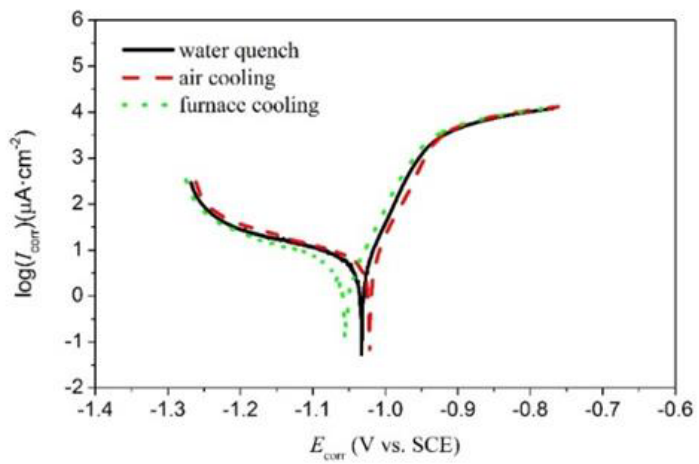

Figure 2. Tafel curves of the $\mathrm{Zn}-\mathrm{Al}-\mathrm{Mg}$ alloy 
Table 3. Electrochemical properties of the Zn-Al-Mg alloy in Fig. 2

\begin{tabular}{lll}
\hline Solidification & $E_{\text {corr }} v s . \mathrm{SCE}(\mathrm{V})$ & $I_{\text {corr }}\left(\mu \mathrm{A} \cdot \mathrm{cm}^{-2}\right)$ \\
\hline Water quench & -1.02 & 5.8 \\
Air cooling & -1.01 & 5.5 \\
Furnace cooling & -1.06 & 3.7 \\
\hline
\end{tabular}

\section{Conclusions}

A Zn-Al-Mg alloy with different solidification processes was prepared. The microstructure of the $\mathrm{Zn}-\mathrm{Al}-\mathrm{Mg}$ cast alloy is composed with a $\mathrm{Zn}$ crystal including slight $\mathrm{Al}$ and a $\mathrm{Zn}-\mathrm{Al}-\mathrm{Mg}$ ternary microstructure. As increasing solidification rate, more $\mathrm{Al}$ is remained in the primary crystal which is rich in $\mathrm{Zn}$. Ternary eutectic microstructure is found in the $\mathrm{Zn}-\mathrm{Al}-\mathrm{Mg}$ alloy, which is compose with a $\mathrm{Zn}$ solution phase, a $\mathrm{Al}$ solution phase and a $\mathrm{MgZn}_{2}$ intermetallic phase. it could be noted that the $\mathrm{Zn}$ content in the $\mathrm{Al}$ solution phase in the eutectic region decreases along with decreasing solidification rate. Tafel curves reveals that the corrosion current density of furnace cooling sample is the lowest, which implies the slowest rate of mass loss and higher corrosion resistance.

\section{References}

1. N. Pistofidis, G. Vourlias, S. Konidaris, E. Pavlidou, A. Stergiou, G. Stergioudis, Mater. Lett. 60, 786 (2006).

2. F. Rosalbino, E. Angelini, D. Maccio, A. Saccone, S. Delfino, Electrochim. Acta 52, 7107 (2007).

3. H. E. Townsend, J. C. Zoccola, Mater. Performance 18, 13 (1979).

4. T. Prosek, A. Nazarov, A. Le Gac, D. Thierry, Prog. Org. Coat. 83, 26 (2015).

5. T. Prosek, N. Larche, M. Vlot, F. Goodwin, D. Thierry, Mater. Corros. 61, 412 (2010).

6. C. Schwerdt, M. Riemer, S. Kohler, B. Schuhmacher, M. Steinhorst, Galvatech '04 Conference Proceedings (Omnipress, Madison, 2004).

7. T. Shimizu, F. Yoshizaki, Galvatech 2011 Proceedings (Associazione Italiana di Metallurgia, Milano,2011).

8. H. Kagechika, Proceedings of 7th International Conference on Zinc and Zinc Alloy Coated Steel Sheet (The Iron and Steel Institute of Japan, Osaka, 2007).

9. G. Angeli, R. Brisberger, M. Bülter, L. Diez, C. Filthaut, W. Fischer, T. Koll, T. Maiwald, C. Pesci, A. Richter, J. Schulz, U. Stellmacher, N. van Landschoot, Proceedings of 9th International Conference on Zinc and Zinc Alloy Coated Steel Sheet \& $2^{\text {nd }}$ Asia-Pacific Galvanizing Conference (Metallurgical Industry Press, Beijing, 2013).

10. R. Ambat, N. N. Aung, W. Zhou, Corros. Sci., 42, 1433 (2000).

11. E. Zhang, D. Yin, L. Xu, L. Yang, K. Yang, Mater. Sci. Eng. C 29, 987 (2009).

12. W. R. Osório, C. M. Freire, A.Garcia, J. Alloys Compd. 397, 179 (2005).

13. S. G. Shabestari, H. Moemeni, J. Mater. Process. Technol. 153, 193(2004).

14. K. Honda, W. Yamada, K. Ushioda, Mater. Trans. 49, 1395(2008).

15. H. Liang, S. -L. Chen, Y. A. Chang, Metall. Mater. Trans. A 28, 1725 (1997).

16. T. Prosek, A. Nazarov, U. Bexell, D. Thierry, J. Serak, Corros. Sci. 50, 2216 (2008).

17. ASM International staff, ASM Handbook: Volume 3: Alloy Phase Diagrams (ASM International, 1992).

18. E. McCafferty, Corro. Sci. 47, 3202 (2005). 